\title{
Relationship between pre-pregnancy BMI and plasma zinc concentrations in early pregnancy
}

\author{
Tsunenobu Tamura ${ }^{1}$, Robert L. Goldenberg ${ }^{2}$, Kelley E. Johnston ${ }^{1}$ and Victoria R. Chapman ${ }^{2}$ \\ ${ }^{1}$ Department of Nutrition Sciences and \\ ${ }^{2}$ Department of Obstetrics and Gynecology, University of Alabama at Birmingham, Birmingham, AL, USA
}

(Received 10 October 2003 - Revised 13 January 2004 - Accepted 30 January 2004)

\begin{abstract}
We previously reported that pregnant women whose plasma $\mathrm{Zn}$ concentrations were below the 50th percentile tended to have high pre-pregnancy BMI $\left(\mathrm{kg} / \mathrm{m}^{2}\right)$ values. We therefore hypothesized that in pregnant women, plasma $\mathrm{Zn}$ concentrations are negatively correlated with BMI. We evaluated the association between BMI values and plasma $\mathrm{Zn}$ concentrations in 1474 women whose blood samples were obtained before 15 weeks of gestation. Their mean age was 22.7 years and mean gestational age at blood sampling was 10 weeks. The mean plasma $\mathrm{Zn}$ concentration and BMI were $11.6 \mu \mathrm{mol} / 1$ and $26.6 \mathrm{~kg} / \mathrm{m}^{2}$ respectively. Because plasma $\mathrm{Zn}$ concentrations decrease as gestational age increases, plasma Zn concentrations were standardized by Z-scores. Z-score distributions were compared among the quartiles of BMI. The highest BMI group had the lowest plasma Zn concentrations, whereas the lowest BMI group had the highest; the differences were significant between the BMI groups $(P<0 \cdot 0001)$. The interpretation of plasma $\mathrm{Zn}$ concentrations to assess $\mathrm{Zn}$ nutriture in pregnancy may be complicated not only by the well-established factor of gestational age at blood sampling, but also by a previously unrecognized factor, maternal BMI.
\end{abstract}

Plasma zinc: Body mass index: Pregnant women

Several groups of researchers have reported that plasma or serum $\mathrm{Zn}$ concentrations are significantly lower in overweight non-pregnant subjects than those in non-overweight control subjects (Atkinson et al. 1978; Chandra \& Kutty, 1980; Chen et al. 1988; Di Martino et al. 1993; Marreiro et al. 2002). Lowy et al. (1986) showed that plasma and erythrocyte $\mathrm{Zn}$ concentrations as well as urinary and faecal $\mathrm{Zn}$ losses are increased during weight-reduction diets in obese men, and Serfass et al. (1983) reported similar findings in young obese women. Although these findings are not always consistent (Collipp, 1984; Tanaka et al. 1993; Marotta et al. 1995; Hashim et al. 1996), they suggest a possible association between the metabolism, transport and/or tissue distribution of $\mathrm{Zn}$ and overweight. None of these studies, however, involved pregnant women.

In a double-blind trial performed in indigent AfricanAmerican women in Birmingham, AL, USA, we reported that prenatal $\mathrm{Zn}$ supplementation had a positive effect on fetal growth (Goldenberg et al. 1995). For that trial the subjects were selected on the basis of plasma $\mathrm{Zn}$ concentrations lower than the 50th percentile (Tamura et al. 2000). This resulted in our unintentionally selecting a group of women with high mean pre-pregnancy BMI of $28.0 \mathrm{~kg} / \mathrm{m}^{2}$ for the trial. Based on these findings and those of others reviewed earlier, we hypothesized that plasma $\mathrm{Zn}$ concentrations are negatively correlated with BMI in pregnant women. To test this hypothesis, we analysed the association between plasma $\mathrm{Zn}$ concentration in early pregnancy and pre-pregnancy BMI in 1474 women who were screened for the trial between 3 and 14 weeks of gestation.

\section{Materials and methods}

Subjects

The Institutional Review Board at the University of Alabama at Birmingham approved the study, and each subject gave signed informed consent. From 1991 to 1993, 1474 pregnant women between 3 and 14 weeks of gestation of all racial and ethnic groups using the Jefferson County Health Department for obstetric care were screened for plasma $\mathrm{Zn}$ concentrations for possible enrolment in a trial to evaluate the effect of $\mathrm{Zn}$ supplementation on pregnancy outcome (Goldenberg et al. 1995; Tamura et al. 2000). These subjects had plasma $\mathrm{Zn}$ concentrations measured, a recorded pre-pregnancy BMI and other pregnancy-related information. The mean maternal age was 22.7 (SD 5.4) years and the ages ranged from 11 to 44 years. The women were (\%): African-American 85.4; white $13 \cdot 4$; other $1 \cdot 2$.

\section{Clinical data and birth weight}

The information on maternal age, pre-pregnancy anthropometric measurements and parity was obtained at the first 
prenatal visit at a mean of 10 weeks of gestation (ranging from 3 to 14 weeks). Maternal height was measured at the first prenatal visit, and BMI was calculated using the prepregnancy body weight reported by the subject at the first prenatal visit as reported previously (Goldenberg et al. 1995). Gestational age at the first visit was estimated based on the first day of the last menstrual period and ultrasound examination. When less than 2 weeks of discrepancy was found between the estimation by the two methods, the gestational age was defined based on the last menstrual period. However, when these two values differed by more than 2 weeks, the gestational age measured by ultrasound was used.

\section{Blood sample collection}

At the first prenatal visit between 3 and 14 weeks of gestation, non-fasting blood samples were obtained using a trace-mineral-free tube with sodium heparin (Vacutainer; Beckton Dickinson, Rutherford, NJ, USA). Samples were refrigerated immediately after drawing until plasma separation, and were then stored at $-70^{\circ} \mathrm{C}$ until $\mathrm{Zn}$ analysis (Tamura et al. 1994).

\section{Plasma zinc determination}

Plasma $\mathrm{Zn}$ concentrations were measured by atomic absorption spectrophotometry. The $\mathrm{CV}$ of the analyses using pooled human plasma samples was about $4 \%$ and the difference in the estimated $\mathrm{Zn}$ values of the standard reference material (no. 1598; National Institute of Standards and Technology, Gaithersburg, MD, USA) was about $6 \%$ (Tamura et al. 1994).

\section{Statistical analyses}

Plasma Zn concentrations were standardized by Z-scores because values decreased as gestational age at blood drawing advanced (Tamura et al. 2000). The Z-score gives the number of standard deviations above or below the mean value on a standard normal curve centred on the mean for each gestational age at blood drawing. We divided the subjects into quartiles of BMI, and the Z-score distribution and other variables were compared using ANOVA. A multiple regression analysis was used to evaluate the factors associated with plasma $\mathrm{Zn}$ concentrations.

\section{Results}

Table 1 shows the characteristics of 1474 mothers divided by quartiles of pre-pregnancy BMI. The mean BMI of all subjects combined was $26.6 \mathrm{~kg} / \mathrm{m}^{2}$. Higher BMI was associated with greater maternal age $(P<0.0001)$. A higher percentage of African-Americans were found in the higher BMI quartiles $(P<0 \cdot 0001)$, whereas the percentage of primiparous women was lower among the subjects with higher BMI $(P<0.0001)$. As expected, the mean birth weights of infants increased as maternal BMI increased $(P=0 \cdot 0007)$.

The overall mean plasma $\mathrm{Zn}$ concentration was 11.6 $\mu \mathrm{mol} / \mathrm{l}$. Table 2 shows plasma $\mathrm{Zn}$ concentrations and 
Table 3. Effect of maternal characteristics on plasma zinc concentrations using multiple regression analyses $(n 1474)^{*}$

\begin{tabular}{lcc}
\hline Maternal characteristics & $\begin{array}{c}\text { Effect size } \\
(\mu \mathrm{mol} / \mathrm{l})\end{array}$ & $\begin{array}{c}\text { Statistical significance } \\
\text { of effect: } P\end{array}$ \\
\hline Age $($ years $)$ & -0.003 & $\mathrm{NS}$ \\
$\mathrm{BMl}\left(\mathrm{kg} / \mathrm{m}^{2}\right)$ & -0.05 & $<0.0001$ \\
Gestational age at & -0.08 & $=0.0004$ \\
blood sampling (weeks) & -0.35 & $=0.047$ \\
Being African-American & 0.18 & $\mathrm{NS}$ \\
Being primiparous &
\end{tabular}

* For details of subjects and procedures, see Table 1 and pp. 773-774.

Z-scores of mothers divided by quartiles of BMI. The results indicate that the subjects with higher BMI had significantly lower plasma $\mathrm{Zn}$ concentrations than those with lower BMI $(P<0 \cdot 0001)$.

The regression analysis performed after adjusting for maternal age, gestational age at blood sampling, race and parity indicated that the increase of 1 unit of BMI $(\mathrm{kg} /$ $\mathrm{m}^{2}$ ) was associated with a $0.05 \mu \mathrm{mol} / 1$ decrease in plasma $\mathrm{Zn}$ concentrations for all subjects combined $(P<0.0001)$. Other factors associated with plasma $\mathrm{Zn}$ concentrations included gestational age at the time of blood drawing ( 1 week of increase was associated with a decrease of $0.08 \mu \mathrm{mol} / 1, P<0.0004)$ and being AfricanAmerican $(0.35 \mu \mathrm{mol} / \mathrm{l}$ lower than being white, $P=0 \cdot 0049$ ), as shown in Table 3 .

\section{Discussion}

In blood samples obtained at less than 15 weeks of gestation, we found that plasma $\mathrm{Zn}$ concentrations decreased as maternal pre-pregnancy BMI increased. Therefore, the interpretation of plasma $\mathrm{Zn}$ concentrations to assess $\mathrm{Zn}$ nutriture in pregnancy is also complicated by pre-pregnancy BMI in addition to gestational age at blood sampling (Hambidge \& Droegemueller, 1974; Tuttle et al. 1985; Tamura \& Goldenberg, 1996; Tamura et al. 2000). Our results are in agreement with others, who have suggested that $\mathrm{Zn}$ metabolism, transport and/or tissue distribution are related to the BMI through a yet-to-be-identified mechanism (Atkinson et al. 1978; Chandra \& Kutty, 1980; Serfass et al. 1983; Lowy et al. 1986; Chen et al. 1988; Di Martino et al. 1993; Marreiro et al. 2002). In addition, our findings are consistent with the observations in animals indicating that tissue $\mathrm{Zn}$ distribution is different in overweight and lean mice and rats (Begin-Heick et al. 1985; Kennedy \& Failla, 1986, 1987; Donaldson et al. 1987). The mechanisms causing such differences are unknown.

It is well established that plasma volume correlates significantly with BMI (Pearson et al. 1995). The lower plasma $\mathrm{Zn}$ concentrations in our subjects with higher BMI may be in part due to the increased plasma volume in these women. In fact, the decreasing plasma $\mathrm{Zn}$ concentrations observed during pregnancy may be due to the expansion of plasma volume seen in nearly all pregnant women. However, we do not know to what extent plasma volume expansion is responsible for decreasing $\mathrm{Zn}$ concentrations, because the relationship between micronutrient status and 
plasma volume during pregnancy has not been extensively studied. There is evidence to suggest that foods rich in micronutrients are associated with greater birth weight and this relationship was attributed to greater expansion in plasma volume (Mardones-Santander et al. 1988). The decrease in plasma $\mathrm{Zn}$ associated with the increase in BMI observed in the present study may be related to our previous reports in which plasma concentrations of albumin and $\alpha_{2}$-macroglobulin were lower in heavier pregnant women than in lighter subjects (Goldenberg et al. 1991; Maher et al. 1993). Because plasma albumin binds about $80 \%$ total plasma $\mathrm{Zn}$ and $\alpha_{2}$-macroglobulin binds about $20 \%$ plasma $\mathrm{Zn}$ as a high-affinity Zn-binding protein (Giroux, 1975), low concentrations of these proteins in heavier pregnant women may account for the lower plasma $\mathrm{Zn}$ concentrations as compared with lighter women. In fact, Campbell \& MacGillivray (1984) reported that there is a significantly positive relationship between intravascular albumin mass and $\mathrm{Zn}$ mass. In addition, low serum $\alpha_{2^{-}}$ macroglobulin concentrations in non-pregnant obese subjects have also been reported in Thailand (Tungtromgchitr et al. 2003). However, at the present time we do not know why these protein concentrations are low in overweight subjects or whether the low protein concentrations are related to the metabolism, transport and/or tissue distribution of $\mathrm{Zn}$. Furthermore, it is unlikely that $\mathrm{Zn}$ nutriture has any influence in regulating BMI.

Another possible reason for the low plasma $\mathrm{Zn}$ concentrations in women with high BMI is that they consume less $\mathrm{Zn}$. However, it is worthwhile noting that in subjects who participated in the $\mathrm{Zn}$ supplementation trial (Goldenberg et al. 1995), there was no significant association between BMI values and dietary energy and $\mathrm{Zn}$ intakes assessed by a $24 \mathrm{~h}$ dietary record (T Tamura \& RL Goldenberg, unpublished results). This finding strongly suggest that dietary energy and $\mathrm{Zn}$ intakes were independent of BMI values among the subjects evaluated in the study presented here, since they were of similar socio-economic backgrounds and dietary habits to those who participated in the trial. Therefore, it is likely that the different plasma $\mathrm{Zn}$ concentrations among different BMI groups found in the present study were not due to differences in dietary energy and $\mathrm{Zn}$ intakes.

Future studies are warranted to identify whether the differences in $\mathrm{Zn}$ concentrations among pregnant women with varying BMI are associated with pregnancy outcome. Low circulating $\mathrm{Zn}$ concentrations may in part contribute to physiological disadvantage during pregnancy among overweight women, since adverse pregnancy outcomes associated with obesity are well recognized (Cnattinguis et al. 1998). The population of obese individuals is increasing at an alarming rate (Yanovski \& Yanovski, 2002); thus, it is important to identify the mechanism of altered $\mathrm{Zn}$ status in obese subjects. It would also be interesting to evaluate whether circulating levels of other nutrients also have an association with BMI in both non-pregnant and pregnant populations.

In summary, we found that the higher the pre-pregnancy $\mathrm{BMI}$, the lower the plasma $\mathrm{Zn}$ concentrations in women whose blood samples were tested before 15 weeks of gestation. Although the changes due to BMI were relatively small, our results indicate that the interpretation of plasma $\mathrm{Zn}$ concentrations to assess $\mathrm{Zn}$ nutriture in pregnancy is complicated by the factor of BMI in addition to the wellestablished factor of gestational age at the time of blood drawing. It is important to take this association into account for the selection of pregnant subjects for future large-scale studies or the interpretation of plasma $\mathrm{Zn}$ data.

\section{References}

Atkinson RL, Dahms WT, Bray GA, Jacob R \& Sandstead HH (1978) Plasma zinc and copper in obesity and after intestinal bypass. Ann Int Med 89, 491-493.

Begin-Heick N, Dalpe-Scott M, Rowe J \& Heick HMC (1985) Zinc supplementation attenuates insulin secretory activity in pancreatic islets of the ob/ob mice. Diabetes 34, 179-184.

Campbell DM \& MacGillivray I (1984) The importance of plasma volume expansion and nutrition in twin pregnancy. Acta Genet Med Gemellol 33, 19-24.

Chandra RK \& Kutty KM (1980) Immunocompetence in obesity. Acta Paediatr Scand 69, 25-30.

Chen M-D, Lin P-Y, Lin W-H \& Cheng V (1988) Zinc in hair and serum of obese individuals in Taiwan. Am J Clin Nutr 48, 1307-1309.

Cnattingius S, Bergström R, Lipworth L \& Kramer MS (1998) Prepregnancy weight and the risk of adverse pregnancy outcomes. N Engl J Med 338, 147-152.

Collipp PJ (1984) New developments in medical therapy of obesity. Pediatr Ann 13, 465-472.

Di Martino G, Matera MG, De Martino B, Vacca C, Di Martino S \& Rossi F (1993) Relationship between zinc and obesity. J Med 24, 177-183.

Donaldson DL, Smith CC \& Koh E (1987) Effects of obesity and diabetes on tissue zinc and copper concentrations in the Zucker rat. Nutr Res 7, 393-399.

Giroux EL (1975) Determination of zinc distribution between albumin and $\alpha_{2}$-macroglobulin in human serum. Biochem Med 12, 258-266.

Goldenberg RL, Tamura T, Cliver SP, Cutter GR, Hoffman HJ \& Davis RO (1991) Maternal serum alpha ${ }_{2}$-macroglobulin and fetal growth retardation. Obstet Gynecol 78, 594-599.

Goldenberg RL, Tamura T, Neggers Y, Copper RL, Johnston KE, DuBard MB \& Hauth JC (1995) The effect of zinc supplementation on pregnancy outcome. J Am Med Assoc 274, 463-468.

Hambidge KM \& Droegemueller W (1974) Changes in plasma and hair concentrations of zinc, copper, chromium, and manganese during pregnancy. Obstet Gynecol 44, 666-672.

Hashim Z, Woodhouse L \& King JC (1996) Interindividual variation in circulating zinc concentrations among healthy adult men and women. Int J Food Sci Nutr 47, 383-390.

Kennedy ML \& Failla ML (1986) Influence of genetic obesity on tissue concentrations of zinc, copper, manganese and iron in mice. J Nutr 116, 1432-1441.

Kennedy ML \& Failla ML (1987) Zinc metabolism in genetically obese (ob/ob) mice. J Nutr 117, 886-893.

Lowy SL, Fisler JS, Drenick EJ, Hunt IF \& Swendseid ME (1986) Zinc and copper nutriture in obese men receiving very low calorie diets of soy or collagen protein. Am J Clin Nutr 43, 272-287.

Maher JE III, Goldenberg RL, Tamura T, Cliver SP, Johnston KE \& Hoffman HJ (1993) Indicators of maternal nutritional status and birth weight in term deliveries. Obstet Gynecol 81, 165-169.

Mardones-Santander F, Rosso P, Stekel A, Ahumada E, Llaguno S, Pizarro F, Salinas J, Vial I \& Walter T (1988) Effect of a milk-based food supplement on maternal nutritional status 
and fetal growth in underweight Chilean women. Am J Clin Nutr 47, 413-419.

Marotta A, Todisco N, Di Toro A, Toraldo R, Ponte G \& Perrone L (1995) Zinc content of lymphocytes in obese children. Nutr Res 15, 1411-1415.

Marreiro DDN, Fisberg M \& Cozzolino SMF (2002) Zinc nutritional status in obese children and adolescents. Biol Trace Elem Res 86, 107-122.

Pearson TC, Guthrie DL, Simpson J, Chinn S, Barosi G, Ferrant A, Lewis SM \& Najean Y (1995) Interpretation of measured red cell mass and plasma volume in adults: expert panel on radionuclides of the International Council for Standardization in Haematology. Br J Haematol 89, 748-756.

Serfass RE, McHugh MZ, Struempler BJ \& Garcia PA (1983) Elemental balance in obese women fed a hypocaloric dietary regimen. Nutr Res 3, 157-170.

Tamura T \& Goldenberg RL (1996) Zinc nutriture and pregnancy outcome. Nutr Res 16, 139-181.

Tamura T, Goldenberg RL, Johnston KE \& DuBard M (2000) Maternal plasma zinc concentrations and pregnancy outcome. Am J Clin Nutr 71, 109-113.
Tamura T, Johnston KE, Freeberg LE, Perkins LL \& Goldenberg RL (1994) Refrigeration of blood samples prior to separation is essential for the accurate determination of plasma or serum zinc concentrations. Biol Trace Elem Res 41, 165-173.

Tanaka S, Inoue S, Isoda F, Waseda M, Ishihara M, Yamakawa T, Sugiyama A, Takamura Y \& Okuda K (1993) Impaired immunity in obesity: suppressed but reversible lymphocyte responsiveness. Int J Obes 17, 631-636.

Tungtrongchitr R, Pongpaew P, Vudhivai N, Changbumrung S, Tungtrongchitr A, Phonrat B, Viroonudomphol D, Pooudong S \& Schelp FP (2003) Relationship between alpha-2-macroglobulin, anthropometric parameters and lipid profiles in Thai overweight and obese in Bangkok. Nutr Res 23, 1143-1152.

Tuttle S, Aggett PJ, Campbell D \& MacGillivray I (1985) Zinc and copper nutrition in human pregnancy: a longitudinal study in normal primigravidae and in primigravidae at risk of delivering a growth retarded baby. Am J Clin Nutr 41, $1032-1041$.

Yanovski SZ \& Yanovski JA (2002) Obesity. N Engl J Med 346, 591-602. 